\title{
PERANCANGAN APLIKASI PEMILIHAN JURUSAN PADA SMK NEGERI 7 SAMARINDA ONLINE DENGAN TOPSIS
}

\author{
*Damar Nurcahyono"), Abdul Najib²), Wahid Kasim³) \\ ${ }^{1,2)}$ Program Studi Teknik Informatika, Politeknik Negeri Samarinda \\ ${ }^{3)}$ Program Studi Teknologi Rekayasa Komputer, Politeknik Negeri Samarinda \\ Email : amar@polnes.ac.id ${ }^{1)}, \underline{\text { abdulnajib@polnes.ac.id }{ }^{2)}}$
}

\begin{abstract}
Abstrak: Penentuan jurusan pada proses Penerimaan Peserta Didik Baru (PPDB) di Sekolah Menengah Kejuruan 7 (SMK 7) sering menjadi permasalahan oleh tim penyeleksi, hal ini dikarenakan banyaknya kriteria yang ditentukan setiap jurusan yang ada dan proses perhitungan nilai-nilai yang kompleks. Penelitian ini membahas mengenai perancangan aplikasi pendaftaran dan pemilihan jurusan pada SMK Negeri 7 Samarinda berbasis online dengan metode Technique For Order Preference by Similiarity to Ideal Solution (TOPSIS), sehingga dapat menjadi pendukung dalam proses penentuan jurusan PPDB.
\end{abstract}

Kata Kunci: Alternatif Jurusan, penerimaan peserta didik baru (PPDB), Sekolah Menengah Kejuruan (SMK) 7, Technique For Order Preference by Similiarity to Ideal Solution (TOPSIS)

\section{PENDAhUluan}

Dalam Proses Penerimaan Peserta Didik Baru (PPDB) SMK 7, terjadi kendala seperti memiliki kriteria yang cukup banyak dalam proses penjurusan bagi peserta didik baru, belum adanya rumusan dan cara yang tepat dari pemerintah yang menghasilkan alternatif jurusan yang diterima peserta didik benar-benar sesuai berdasarkan kriteria yang ditetapkan. Pihak sekolah selama ini melakukan proses penjurusan secara manual dengan mengambil kriteria yang ditetapkan mandiri oleh pihak sekolah dan menggabungkan kriteria yang ada pada peraturan pemerintah. Hal ini mengakibatkan lamanya waktu yang dibutuhkan untuk melakukan proses perhitungan penilaian. Technique For Order Preference by Similiarity to Ideal Solution (TOPSIS) merupakan salah satu metode untuk penyelesaian masalah

\section{METODE PENELITIAN}

A. Kriteria Penilaian PPDB

Kriteria penilaian yang digunakan sebagai persyaratan masuk bagi calon peserta didik baru ke SMK Negeri 7 yakni : rata- rata nilai UN SMP / MTs sederajat, rata - rata nilai rapor kelas VIII dan kelas IX semester ganjil, ratarata Ujian Sekolah, rata - rata Nilai Seleksi Bakat dan Minat. Yang dirumuskan sebagai berikut :

$$
\underline{P+Q+2 R+2 S}
$$

\section{6}

Keterangan :

$\mathrm{NA}=$ Nilai Akhir

$\mathrm{P}=$ Rata-rata nilai rapor kelas VIII dan kelas IX semester ganjil pengambilan keputusan berdasarkan pada banyak kriteria atau atribut yang biasa kita kenal dengan Multi Criteria Decision Making (MCDM) TOPSIS didasarkan pada konsep dimana alternatif terpilih yang terbaik tidak hanya memiliki jarak terpendek dari solusi ideal positif, namun juga memiliki jarak terpanjang dari solusi ideal negatif. Hal inilah yang menarik peneliti untuk melakukan penelitian mengenai perancangan aplikasi pendaftaran dan penentuan jurusan sekolah menengah kejuruan menggunakan metode TOPSIS. Dengan metode TOPSIS ini, proses pengkalkulasian nilai dan berbagai atribut kriteria yang ditentukan dapat diolah dengan baik sehingga mendapatkan hasil alternatif jurusan terbaik untuk peserta didik baru. Dengan demikian, diharapkan penelitian ini dapat membantu tim PPDB sekolah menengah kejuruan dalam proses penentuan jurusan peserta didik baru.

$$
\begin{aligned}
& \mathrm{Q}=\text { Rata-rata nilai Ujian Sekolah } \\
& \mathrm{R}=\text { Rata-rata nilai Ujian Nasional } \\
& \mathrm{S}=\text { Nilai tes basis kompetensi }
\end{aligned}
$$

\section{B. Metode TOPSIS}

Technique for OrderPreference by Similiarity to Ideal Solution (TOPSIS) merupakan salah satu metode untuk penyelesaian masalah pengambilan keputusan berdasarkan pada banyak kriteria atau atribut yang biasa kita kenal dengan Multi Criteria Decision Making (MCDM) TOPSIS didasarkan pada konsep dimana alternatif terpilih yang terbaik tidak hanya memiliki jarak terpendek dari solusi ideal positif, namun juga memiliki jarak terpanjang dari solusi ideal negatif. Langkah-langkah penyelesaian masalah MCDM dengan menggunakan metode TOPSIS adalah sebagai berikut :

1. Membuat matriks keputusan yang ternormalisasi. 
2. Membuat matriks keputusan yang ternormalisasi terbobot.

3. Membuat matriks solusi ideal positif dan matriks solusi ideal negative.

4. Menentukan jarak antara nilai setiap alternatif dengan matriks solusi ideal positif dan matriks solusi ideal negative.

5. Menentukan nilai preferensi untuk setiap alternative.

\section{HASIL DAN PEMBAHASAN}

\subsection{Analisis Proses PPDB di SMK 7}

Sistem lama yang digunakan SMK Negeri 7 dalam menentukan jurusan untuk peserta didik pada proses penerimaan peserta didik baru sebagai berikut:

1. Calon siswa melakukan pendaftaran sendiri ke sekolah dengan melengkapi Berkas yang telah ditentukan yaitu fotocopy raport, ijazah atau SKHU, pas foto.

2. Tim PPDB melakukan verifikasi keabsahan dan kelengkapan berkas, jika berkas lengkap maka calon siswa akan mendapatkan nomor pendaftaran sebagai identitas untuk mengikuti tes/ujian saringan masuk yang dilakukan oleh pihak sekolah, namun jika tidak maka berkas akan dikembalikan ke calon siswa.

3. Proses ujian yang dilakukan sekolah ada 4 macam, yakni tes basic kompetensi, ujian bidang studi Matematika, ujian bidang studi Bahasa Inggris dan ujian bidang studi Komputer.

4. Setelah ujian saringan masuk dilaksanakan, maka Tim PPDB akan melakukan pengolahan nilai calon siswa untuk mendapatkan Nilai Akhir (NA) pada Rumus (1) yang dapat kita sebut NA

5. Tim PPDB kemudian mengurutkan nilai calon siswa dari yang tertinggi hingga terendah, sehingga tersaring jumlah yang sesuai kuota yang ditetapkan untuk diterima yang nantinya akan dilakukan penentuan jurusannya

6. Setelah selesai melakukan erhitungan NA 1, maka Tim PPDB akan melakukan kembali pengolahan data nilai untuk proses penentuan jurusan yang diperkirakan paling potensial untuk calon siswa tersebut merujuk pada batasan/range nilai untuk jurusan(tabel 1)

Tabel 1. Batasan Nilai Jurusan

\begin{tabular}{ll}
\hline Jurusan & Batasan Nilai \\
\hline TKJ & $>8,00$ \\
Multimedia & $>7,50-8,00$ \\
RPL & $>7,00-7,50$ \\
\hline
\end{tabular}

7. Setelah didapatkan data jurusan mana yang diperkirakan paling cocok tersebut, maka tahapan selanjutnya yang dilakukan oleh Tim PPDB adalah mendata kemampuan ekonomi calon siswa sebagai pertimbangan dan mengingat kriteria-kriteria yang ditentukan oleh masing-masing jurusan. Data kemampuan ekonomi ini didapat dari biodata calon siswa tentang pekerjaan dan penghasilan orang tua/wali nya.

8. Tim beserta seluruh pihak terkait dalam proses PPDB akan melakukan rapat akhir untuk membahas jurusan yang paling tepat untuk calon siswa dan kuota siswa yang akhirnya diterima untuk tahun ajaran baru.

3.2 Analisa Sistem Yang akan dibangun menggunakan TOPSIS

Sistem baru yang akan dibangun memanfaatkan sistem pendukung keputusan dengan menggunakan metode TOPSIS memiliki beberapa data masukan yaitu data calon peserta didik baru, data nilai rapor, data nilai tes basic kompetensi, data nilai ujian saringan masuk bidang studi (matematika, bahasa inggris dan komputer) dan data kuota penerimaan yang akan di-input-kan oleh administrator. Sedangkan data yang telah tersimpan dalam sistem sebagai dasar yang digunakan untuk proses penentuan jurusan menggunakan metode TOPSIS yaitu kriteria penentuan jurusan (tabel 2), alternatif jurusan (tabel 3), konversi penilaian untuk kemampuan ekonomi(tabel 4) dan matriks bobot kepentingan/pengaruh antara alternatif dengan setiap kriteria(tabel 5).

Tabel 2. Kriteria Penetuan Jurusan

\begin{tabular}{ll}
\hline Kriteria & \multicolumn{1}{c}{ Keterangan } \\
\hline C1 & Nilai Akhir (NA) 1. \\
C2 & Nilai Ujian Saringan Masuk Bidang Studi \\
C3 & Nilai Ujian Saringan Masuk Bidang Studi Bahasa \\
C4 & Nilai Ujian Saringan Masuk Bidang Studi \\
C5 & Kemampuan Ekonomi Orangtua Calon Peserta Didik \\
\hline
\end{tabular}

Tabel 3. Alternatif Jurusan

\begin{aligned} & \hline Alternatif \multicolumn{1}{c}{ Nama Jurusan } \\ & \hline A1 Teknik Komputer Jaringan \\ & A2 Multimedia \\ & A3 Rekayasa Perangkat Lunak \\ & \hline\end{aligned}

Tabel 4. Penilaian Kemampuan Ekonomi

\begin{tabular}{llc}
\hline Kategori & Penghasilan & Nilai \\
\hline Sangat Mampu / & $>5.000 .000,-$ & 9,00 \\
Mampu & $>1.500 .000,-$ s/d 5.000.000,- & 8,00 \\
Tidak Mampu & $>500.000,-$ s/d 1.500.000,- & 7,00 \\
Sangat Tidak & $=<500.000,-$ & 6,00 \\
\hline
\end{tabular}


Tabel 6 Kuota Penerimaan Siswa Baru

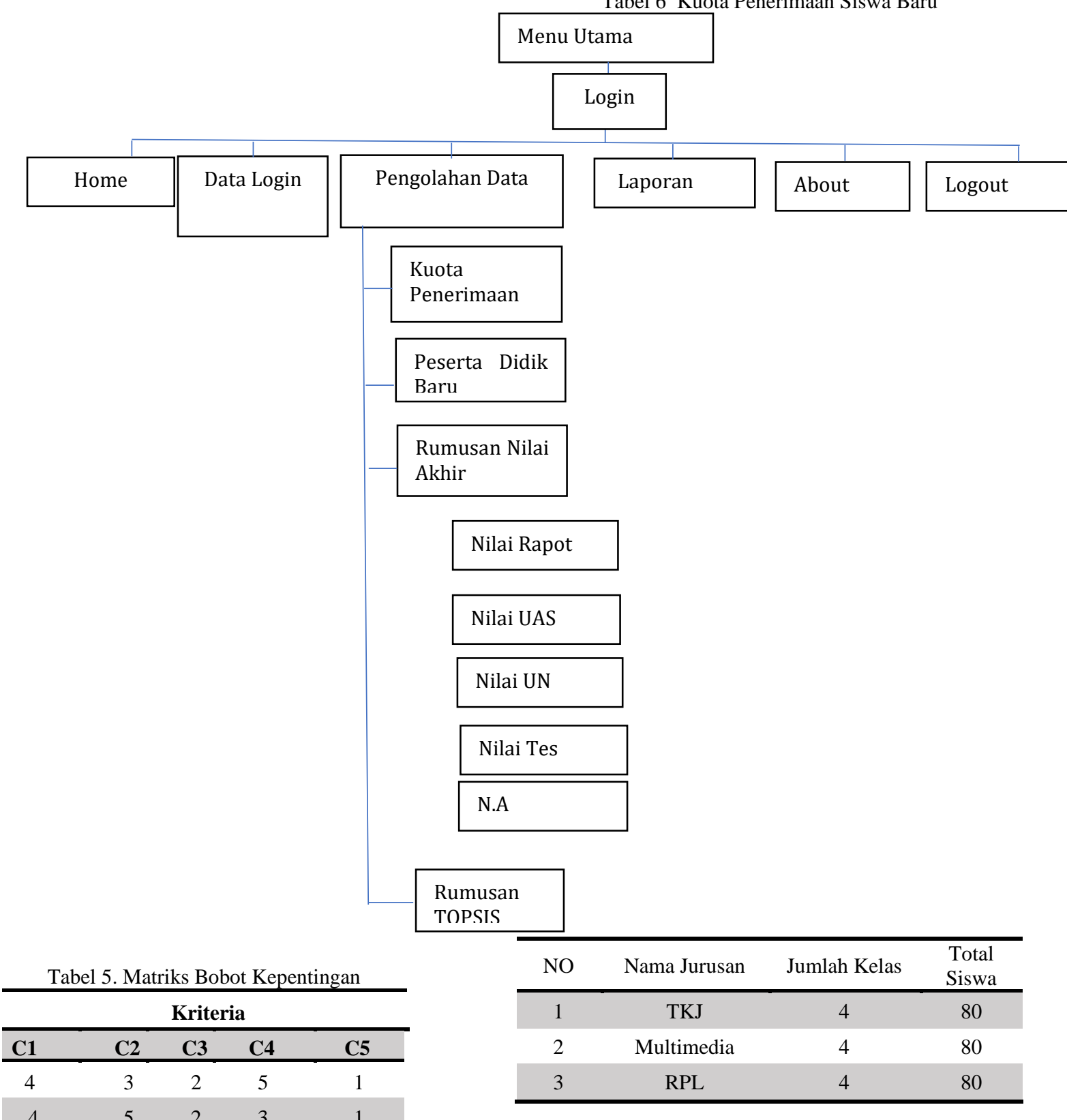

2. Proses Perhitungan Nilai Akhir

\subsection{Perancangan Struktur Menu}

Pada tahap perancangan struktur menu, terdapat tiga proses yaitu: penetapan kuota penerimaan, perhitungan nilai akhir, dan proses TOPSIS. Berikut ini adalah penjelasan tiap proses:

\section{Proses Penetapan Kuota Penerimaan}

Penetapan kuota penerimaan siswa baru dapat dilihat pada tabel 6. Dimana setiap jurusan masing-masing memiliki jumlah kelas 4 dengan total jumlah siswa maksimum adalah 80 siswa per jurusan.

$$
\begin{aligned}
& (\mathrm{NA} \mathrm{1})=[8,32+8,28+(2 \times 7,86)+ \\
& (2 \times 8,30)] / 6=8,15
\end{aligned}
$$

\section{Proses TOPSIS}

Langkah 1 :

Membuat matriks hasil kali antara nilai kriteria dengan matriks bobot kepentingan /pengaruh antara alternatif dan tiap kriteria. Langkah 2 :

Membuat matriks keputusan ternormalisasi.

\section{Langkah 3 :}

Membuat Matriks Keputusan Ternormalisasi Terbobot Untuk membuat 
matriks keputusan ternormalisasi terbobot adalah dengan cara melakukan perkalian matriks R (matriks keputusan ternormalisasi, tabel 9) dengan bobot preferensi (masukan nilai C1, C2, C3,C4 dan C5) yang lebih jelas dapat kita lihat pada tabel 7 nilai dari masingmasing kriteria. Sehingga kita akan memperoleh hasil matriks Y.

\section{Langkah 4 :}

Menentukan Solusi Ideal Positif Untuk menentukan solusi ideal positif adalah dengan cara membandingkan setiap baris pada sebuah kolom, yang memiliki nilai tertinggi (MAX) pada baris di kolom tersebut merupakan solusi ideal positif dari kolom tersebut. tabel yang dijadikan acuan untuk menentukan solusi ideal positif ini adalah tabel 10 matriks keputusan ternormalisasi terbobot (Y).

\section{Langkah 5 :}

Menentukan Solusi Ideal Negatif Untuk menentukan solusi ideal positif adalah dengan cara membandingkan setiap baris pada sebuah kolom, yang memiliki nilai terendah (MIN) pada baris di kolom tersebut merupakan solusi ideal negatif dari kolom tersebut. tabel yang dijadikan acuan untuk menentukan solusi ideal negatif ini adalah tabel 10 matriks keputusan ternormalisasi terbobot $(\mathrm{Y})$.

\section{Langkah 6 :}

Menentukan Jarak Jntara Nilai Terbobot Setiap Alternatif Terhadap Solusi Ideal Positif. Untuk menentukan jarak antara nilai terbobot setiap alternatif terhadap solusi ideal positif, kita perhatikan matriks $\mathrm{Y}$ dan nilai $\mathrm{A}+$, lalu hitung dengan rumus.

\section{Langkah 7 :}

Menentukan Jarak Antara Nilai Terbobot Setiap Alternatif Terhadap Solusi Ideal Negatif Untuk menentukan jarak antara nilai terbobot setiap alternatif terhadap solusi ideal negatif, kita perhatikan matriks Y dan nilai A, lalu hitung dengan rumus (9).

\section{Langkah 8 :}

Menentukan Kedekatan Setiap Alternatif Terhadap Solusi Ideal Untuk menentukan kedekatan setiap alternatif terhadap solusi ideal, kita mempergunakan rumus (10). Berdasarkan langkah ini, metode TOPSIS telah menemukan alternatif jurusan yang terbaik untuk calon peserta didik, yakni V1 yang bernilai tertinggi, maka jurusan yang terbaik berdasarkan perhitungan metode TOPSIS adalah alternatif jurusan pertama yakni Jurusan Teknik Komputer Jaringan.

\section{KESIMPULAN}

Pada penelitian yang dilakukan ini, diperoleh kesimpulan :

1. Sistem penentuan jurusan yang dibangun ini memungkinkan Tim PPDB untuk melihat seluruh data berupa laporan/report calon siswa baru yang mendaftar, yang diterima. sesuai kuota dan jurusan yang sesuai untuk calon siswa yang telah diterima.

2. Tercapainya proses penentuan jurusan menggunakan metode TOPSIS pada SMK 7 memberikan rekomendasi hasil yang lebih objektif dan keterbukaan penilaian berdasarkan perhitungan-perhitungan yang ada.

3. Dalam proses pengolahan data, perhitungan terhadap nilai-nilai lebih mudah, terstruktur dan dapat dilihat secara rinci karena telah terkomputerisasi.

4. Jurusan terbaik yang direkomendasikan oleh sistem adalah nilai akhir dari perhitungan metode TOPSIS yang memiliki nilai akhir terbesar.

\section{REFERENSI}

[1] Azmi, M,. "Sistem Pendukung Keputusan untuk Memilih Usaha Waralaba Makanan Menggunakan Metode TOPSIS", Jurnal Elektro, vol. 5 N0.2 ISSN:2085-6989, Desember 2013.

[2] Ban, I. ,. O.,. Fuzzy Multicriteria Decision Making Method Applied To Selection Of The Best Touristic Destinations. International Journal Of Mathematical Models And Methods In Applied Sciences, 5(2), pp. 264-271. 2011

[3] Daihani, Dadan Umar,. Sistem Pendukung Keputusan, Penerbit Elex Media Komputindo, Jakarta. 2001

[4] Fitriana, A. N,. Sistem Pendukung Keputusan untuk menentukan Prestasi Akademik Siswa dengan Metode TOPSIS, Creation Information Technology Journal 2(2), 153-164, 2015.

[5] Haris,. Metode Penelitian Kualitatif untuk Ilmu-ilmu Sosial. Jakarta: Salemba Humanika. 2010

[6] Kurniasih, D. L.. Sistem Pendukung Keputusan Pemilihan Laptop dengan Metode Topsis, Pelita Informatika Budi Darma, Vol 3 No.2, April 2013.

[7] Kusumadewi, Sri.. Aplikasi Logika Fuzzy untuk Pendukung Keputusan, Graha Ilmu, Yogyakarta. 2010.

[8] Moleong, Lexy,. Metodologi Penelitian Kualitatif, PT. Remaja Rosdakarya, Bandung, 2012

[9] Sugiyono.. Metode Penelitian Kuantitatif Kualitatif dan $R \& D$. Bandung : ALFABETA. 2008

[10] Sukardi,. Metode Penelitian Pendidikan, Jakarta: Bumi Aksara. 2010. 
JUST TI: (Jurnal Sains Terapan Teknologi Informasi) 12, 2 (Juli, 2020): 26-30 ISSN: 2579-4510(online) ISSN: 2085-6458(print)

[11] Turban, Efraim, Sistem Pendukung Keputusan dan Sistem Cerdas, Andi, Yogyakarta. 2005. 